Further economies will depend on a better knowledge of plant products, and particularly on the form that balancer meals for fodder beet and potatoes should take.

\title{
REFERENCES
}

Baker, F. S. Jr. (1949). Bull. Fla agric. exp. Sta. no. 458.

Black, D. J. G. (1953). Private communication.

Braude, R. \& Mitchell, K. G. (1949-50). Agriculture, Lond., 56, 369.

Brown, W. O. (1950). F. Sci. Fd Agric. r, 219.

Carpenter, K. J. (1952). Int. Congr. Anim. Husb. vi. Copenhagen, 2, 68.

Carpenter, K. J. \& Duckworth, J. (1951a). F. agric. Sci, 41, 297.

Carpenter, K. J. \& Duckworth, J. (195 Ib). World's Poult. Congr. IX. Paris, 2, 18.

Carpenter, K. J., Duckworth, J. \& Ellinger, G. M. (1954). F. agric. Sci. (In the Press.)

Carpenter, K. J., Duckworth, J., Ellinger, G. M. \& Shrimpton, D. H. (I953). Unpublished data.

Carpenter, K. J., Duckworth, J. \& Lucas, I. A. M. (1953). Unpublished data.

Catron, D. V., Jensen, A. H., Homeyer, P. G., Maddock, H. M. \& Ashton, G. C. (r952). F. Anim. Sci. II, 221 .

Duckworth, J. (1952). Chem. E Ind. p. I 139.

Duckworth, J. \& Ellinger, G. M. (1949). Brit. F. Nutr. 3, 253.

Dunkin, A. C. \& Cooper, M. M. (1949-50). Agriculture, Lond., 56, 364.

Ellis, N. R. \& Zeller, J. H. (1934). Bull. U.S. Dep. Agric. no. 413.

Evans, R. E. (1952). Ұ. agric. Sci. 42, 438.

Eyles, D. E. (1953). Private communication.

Frens, A. M. (I953). Private communication.

Hughes, E. H., Crampton, E. W., Ellis, N. R. \& Loeffel, W. J. (1950). Recommended Nutrient Allowances for Domestic Animals. no. 2. Recommended Nutrient Allowances for Swine, revised ed. Washington, D.C.: National Research Council.

Jespersen, J. \& Hansen, V. E. H. (1953). Beretn. forsøgslab. no. 264.

Orr, J. B., Moir, M., Kinross, A. \& Robertson, G. S. (1925). Scot. F. Agric. 8, 263.

Prentice, J. H. (1933). F. Minist. Agric. N. Ire. 4, I16.

Robertson, G. S. \& Baskett, R. G. (I929). F. Minist. Agric. N. Ire. 2, I.

Robinson, H. G. (I948-9). Agriculture, Lond., 55, 423.

Shaw, R. B. \& Nightall, E. W. (195I). World's Poult. Sci. F. 7, 202.

Shrimpton, D. H. (1953). Unpublished data.

Sim, A. H., Browning, D. R. \& Walsh, W. A. (1952-3). Agriculture, Lond., 59, 469.

Temperton, H. \& Dudley, F. J. (1944). Harper Adams Util. Poult. F. 29, 24.

Thompson, J. K. (1940). Kirton agric. F. 6, 2 I.

Woodman, H. E. (1952). Bull. Minist. Agric., Lond., no. 48.

Woodman, H. E. \& Evans, R. E. (1948). F. agric. Sci. 38, 200.

Woodman, H. E. \& Evans, R. E. (I95I). F. agric. Sci. 4I, I02.

\section{The Role of the Nutrition Adviser in Livestock Production}

\section{By A. Eden, Ministry of Agriculture and Fisheries National Agricultural Advisory Service (Eastern Province), Anstey Hall, Trumpington, Cambridge}

To be an efficient and successful adviser on matters of live-stock feeding requires a practical and realistic outlook. The adviser must have a good working knowledge of agricultural practices, especially of animal husbandry, and he should have had a sound training in agricultural chemistry, preferably after taking a degree in pure science. His main duties are to translate into practical terms the fundamental facts of nutritional science, to keep abreast of all new developments and advances in nutrition, and as far as possible to keep the research worker aware of the problems 
of animal feeding that he encounters in the course of his work. He should thus be the connecting link between the practical farmer and the laboratory investigator; occasionally he has to become an investigator himself in the search for the solution of a particular nutritional problem.

In practice, he assumes a number of different roles in the discharge of these duties. He may be an adviser in a commercial undertaking, an independent consultant, a press adviser, a chemical consultant, a university or college teacher of animal nutrition or an advisory officer appointed by a ministry or a state department. He has to deal with queries by correspondence, verbally or in the columns of the press, and very often he is called on to pay visits to farms in order to provide the most effective advice on a specific problem. Whatever particular part he has to play his function is primarily one of educating the farmer to make the best use of nutritional knowledge in feeding livestock, and that function demands, except for the simplest type of query, a personal visit to the farm to assess the particular problem he is called upon to assist in solving.

The problems of livestock nutrition are many and varied, ranging from the very simple to the highly complex. Perhaps the most straightforward is the construction of suitable rations for cattle, sheep, pigs and poultry from standard ingredients. The farmer wants to know what to feed and how much to feed, and the answer to such query can readily be given by drawing up rations based on the known nutritional requirements of each particular species of livestock. The problem becomes a little more complicated when feeding-stuffs of rather variable quality are being used, and the resources of a well-organized laboratory are essential for the analysis of such foods as an aid to furnishing the most effective advice. Here the need for the adviser to be well acquainted with practical feeding systems is paramount, for both the qualitative and the quantitative aspects of the problem have to be considered. The advice given must be not only nutritionally sound and effective but also capable of ready implementation in practice. Where analysis is involved the person submitting the sample should be well acquainted with the principles of taking adequately representative samples of the food to be analysed, in order that the advice given shall be directly related to the bulk of the material which it is proposed to feed.

More complex problems of nutrition generally demand a personal visit to the farm and discussions with the farmer and, perhaps, his stockmen to ascertain the full facts and circumstances of the particular problem. Preliminary information given by letter or over the telephone may be somewhat misleading, and an important part of an adviser's duties is to check and cross-check the facts of the situation before committing himself to specific advice. The securing of this information is vital to the success of the recommendations, and calls for considerable tact and diplomacy, and it is most important for the adviser to talk to the farmer in non-technical language and to frame his questions in such a way that there is no ambiguity in the answers.

On occasions it may be necessary for the adviser to make an experimental approach to a particular problem, and the design of experiments on the feeding of 
farm animals must necessarily be very simple. Statistical layouts and replications, though necessary, may be impracticable in the circumstances of the farm and of the nature of the problem, and since it is impossible to give personal daily supervision to the feeding, much has to be left to the farmer and his staff to see that the feeding programme is carried through as laid down. So many errors can creep into farm-scale feeding experiments that it is hardly surprising that the literature contains so few records of this type of work.

Perhaps the most difficult problem that confronts the nutrition adviser is the regional or national type of problem which involves numerous investigations and requires long-term study, for example grass tetany and bloat in cattle. It is difficult to say whether these are primarily problems of nutrition, physiology or pathology, though they appear to be associated with certain general circumstances of feeding. The nutrition adviser, whose services are enlisted on such problems, has to admit to his client the paucity of present knowledge, and further he has often to tell him that there is little or nothing that can be done to help him. The adviser also knows that problems of this nature do not offer the same prospect of positive results to the research worker as shorter-term problems capable of more ready resolution.

Farmers who seek advice also fall into a number of categories. The elementary facts and principles of animal nutrition are still unknown to a minority, and to this group any knowledge is new knowledge. Moreover this is the most difficult class of farmer for the adviser to reach and to get to know. The majority of farmers have some knowledge of basic principles of animal feeding, largely through experience, mutual contacts, trade literature and articles in the farming press. Unfortunately, because of their imperfect knowledge, they may be exploited at times by sensational reports of the virtues of new products. There is also a small minority of well-read, well-educated farmers who know the answers to ordinary questions of nutrition, but who are constantly seeking fuller information on new developments. Their knowledge and enthusiasm result in a high degree of efficiency in their general livestock management and feeding and often they run into a greater proportion of really difficult problems because of this efficiency, for example their high-yielding dairy cows may be more difficult to get into calf, and they may get more than their fair share of trouble with metabolic disorders. The adviser who has to deal with such clients is often closely questioned on new discoveries by the research institutes, and hence he must keep alive to all new developments. It is not an easy matter for the full-time adviser to read all relevant literature, and he is very dependent on, and very grateful for, good review articles and publications on new topics emanating from research institutes.

The nutrition adviser, as the link between the farmer and the research worker, has to view all new discoveries with a certain amount of caution, and he must be ready to interpret such discoveries in the light of the practical conditions of the farm. The greater part of his work is still concerned with putting over to the farmer the older and well-established principles of feeding, and the single greatest contribution he can make to livestock production is to disseminate as widely as possible the concept of balanced rations. His main function is primarily one of education, 
and despite all modern advances in the technique of education-lectures, broadcasting, television, articles, the press-his greatest problem is to reach the farmer who is still ignorant of nutritional principles and who, presumably, is still unwilling to learn except by the process of trial and error.

The adviser has frequently to play down sensational claims for the virtues of particular processes, techniques and feeding-stuffs. One of his most difficult tasks is to resist being involved in lengthy and costly analyses of soils, herbage and feeding-stuffs for minor elements. The average farmer has become more and more trace-element conscious. Any unusual trouble with his livestock or falling off in production is apt to be put down to a condition of nutritional deficiency, and unfortunately there is a tendency to ask a university or government advisory service for almost unlimited analysis for minor elements, without any thought being given to the great difficulty of interpreting the results after the analysis has been completed. A ministry adviser usually deals with such requests by paying a personal visit to the farm and discussing the problem and the difficulties of the request with the farmer. In most instances, some gross error in management or in feeding can be brought to light in a preliminary examination, and the lengthy and costly trace-element investigation can be avoided. So often an alleged deficiency condition in livestock can be associated with bad feeding practices. Loose terminology in referring to such conditions as milk fever and grass tetany as deficiency diseases leads farmers into believing that such conditions can be prevented by feeding specific mineral supplements, and not all advisers are unanimous in their views on such matters.

The relationship between the adviser and the farmer having been discussed, the link between the adviser and the research institutes has also to be considered. It is doubtful whether sufficient use is being made of the adviser to bring to the notice of the research worker the problems of farming practice. How is the research worker to get to know what are the most pressing problems of the farming industry, and how far is he preoccupied with problems of his own choosing to the exclusion of matters of urgent practical moment? It is generally agreed that too little agricultural research work has been done in Great Britain, and there should be no curbing of fundamental research which may or may not have some immediate or remote practical application. But it is evident that there has been too little investigation into problems affecting the individual farm, and there seems to be a good case for more full-time research workers attached to institutes, universities and agricultural colleges to carry out investigations under farm conditions. The argument that such workers require laboratory facilities could be met by the provision of mobile laboratory vans. The adviser would serve as the co-ordinating link to draw the research worker's attention to the problem. Too little applied nutritional research work is going on in Britain at present, and too few research workers have much conception of the problems that await their attention on the farm. Close contact with farming conditions and practices would have a beneficial effect on the research schools and their staffs.

The broad function of the adviser is thus to educate, and the further spread of knowledge of nutritional principles and practices must ultimately lead to more efficient use of feeding-stuffs and hence to more efficient livestock production. 